\title{
ASSOCIATION BETWEEN NURSING STUDENTS' ACADEMIC AND SOCIODEMOGRAPHIC CHARACTERISTICS AND STRESS
}

\author{
Susan Bublitz', Laura de Azevedo Guido², Luis Felipe Dias Lopes³, Etiane de Oliveira Freitas ${ }^{4}$
}

\footnotetext{
${ }^{1}$ Doctoral student, Nursing Post Graduation Program (PPGENF), Universidade Federal de Santa Maria (UFSM). Nurse, Hospital Universitário de Santa Maria (HUSM). Santa Maria, Rio Grande do Sul, Brazil. E-mail: susan.bublitz@gmail.com

2 Ph.D. in Nursing. Professor, PPGENF/UFSM. Santa Maria, Rio Grande do Sul, Brazil. E-mail: lguido344@gmail.com

${ }^{3}$ Ph.D. in Production Engineering. Professor, Department of Administration Sciences UFSM. Santa Maria, Rio Grande do Sul, Brazil. E-mail: 1flopes67@yahoo.com.br

${ }^{4}$ Doctoral student, PPGENF/UFSM. Santa Maria, Rio Grande do Sul, Brazil. E-mail: etiof@yahoo.com.br
}

\begin{abstract}
This study was aimed at investigating the association between the stress levels of nursing students and their sociodemographic and academic characteristics. This quantitative, analytical and cross-sectional study was conducted in four Brazilian higher education Institutions. Data were collected from April 2011 to March 2012, using a sociodemographic and academic tool form for the students and the Assessment of Stress Among Nursing Students. 705 students participated and the results showed a predominance of medium stress levels, followed by high stress levels. Statistically significant differences were found for stress and age group, institution type (public/ private), work activity, satisfaction with the course and if the student had ever thought of dropping out of the course. This study showed that education is assessed as a stressor and that there is an association between the nursing students' characteristics and the stress level.
\end{abstract}

DESCRIPTORS: Nursing. Students, nursing. Higher education institutions. Education, higher. Stress, psychological.

\section{ASSOCIAÇÃO ENTRE ESTRESSE E CARACTERÍSTICAS SOCIODEMOGRÁFICAS E ACADÊMICAS DE ESTUDANTES DE ENFERMAGEM}

\begin{abstract}
RESUMO: Objetivou-se verificar a associação entre estresse de discentes de enfermagem e as características sociodemográficas e acadêmicas dos mesmos. Trata-se de um estudo quantitativo, analítico e transversal, desenvolvido em quatro instituições de ensino superior brasileiras. A coleta dos dados ocorreu entre abril de 2011 a março de 2012, por meio de um formulário sociodemográfico e acadêmico dos discentes e um instrumento para Avaliação de Estresse em Estudantes de Enfermagem. Participaram 705 acadêmicos, com predomínio destes em médio nível de estresse, seguido pelo alto nível de estresse. Quanto às associações, verificou-se diferenças estatísticas significativas entre estresse e as variáveis: faixa etária, tipo de instituição (pública/privada), atividade de trabalho, satisfação com o curso e se já pensou em desistir do curso. Esse estudo permitiu considerar que a formação acadêmica é avaliada como estressora e existe associação entre nível de estresse e as características dos discentes de enfermagem.
\end{abstract}

DESCRITORES: Enfermagem. Estudantes de enfermagem. Instituições de ensino superior. Educação superior. Estresse psicológico.

\section{ASOCIACIÓN ENTRE ESTRÉS Y CARACTERÍSTICAS SOCIODEMOGRÁFICAS Y ACADÉMICAS DE ESTUDIANTES DE ENFERMERÍA}

\begin{abstract}
RESUMEN: Este estudio tuvo como objetivo investigar la asociación entre el estrés de los estudiantes de enfermería y las características sociodemográficas y académicas. Estudio cuantitativo, analítico y transversal realizado en cuatro instituciones de educación superior de Brasil. Los datos se recolectaron entre abril de 2011 y marzo de 2012, a través de una encuesta socio-demográfica y académica entre los estudiantes, y el instrumento de Evaluación del Estrés en Estudiantes de Enfermería. Participaron 705 estudiantes, de los cuales hubo un predominio de nivel medio de estrés, seguido por un alto nivel de estrés. En cuanto a las asociaciones, se encontraron diferencias estadísticas significativas entre el estrés y las variables: edad, el tipo de institución (pública/privada), actividad laboral, satisfacción con la carrera y el pensamiento acerca de renunciar a la misma. Este estudio nos permite considerar que la educación es evaluada como estresante y hay asociación entre el nivel de estrés y las características de los estudiantes de enfermería.
\end{abstract}

DESCRIPTORES: Enfermería. Estudiantes de enfermeira. Instituciones de enseñanza superior. Educación superior. Estrés psicológico. 


\section{INTRODUCTION}

According to the interactionism model, stress is defined as any circumstance that threatens or is perceived to threaten one's well-being and thereby tax one's coping abilities. ${ }^{1}$ Stress on different healthcare workers has been studied, ${ }^{2-4}$ including nurses. Nursing has been considered stressful due to the particularities of its work process. ${ }^{4}$

However, some studies have shown that the professional training of nurses has been identified as stressful by university students, ${ }^{5-7}$ who have to administer personal and social life, the requirements of the university where they study and the preparation for their professional career. ${ }^{8}$ In addition, the transition from academic to professional life is a period that involves important personal decisions such as where and when to start the professional career and when to start a family and assume financial responsibilities. ${ }^{9}$

Stress occurs in the academic environment when the student assesses the demand as being greater than the resources he has. ${ }^{10}$ Stress on students can affect their well-being, capacity of concentration and memorization, academic performance and interfere in interpersonal relationships. ${ }^{11,12}$

Stress interferes on the quality of the teachinglearning process of nursing students, and its occurrence can be related to the students' academic and sociodemographic aspects. ${ }^{13}$ It is therefore important to verify the association between these aspects and stress in order to minimize it and think of ways in which to face it. The following question is asked: "Is there an association between stress and the academic and sociodemographic characteristics of nursing students?"

The objective of this study was to verify the association between stress among nursing students and their academic and sociodemographic characteristics.

\section{METHOD}

This was quantitative, analytical and crosssectional study developed with nursing students in four higher education institutions in the southern and southeastern regions of Brazil.

The study population consisted of students regularly enrolled in Nursing Graduation Courses, aged 18 years or older. The exclusion criteria were the following: special or exchange students; students not enrolled in the professional cycle disciplines; students who had not concluded the syllabus due to exceeding the time limits for each course at the time the data were collected, and students who participated as investigators in this study.

The academic and sociodemographic data were collected using a form that included the following variables: sex, age group, residential status, sports practice, leisure activities, work activity, satisfaction with the course and if the student had ever thought of dropping out of the course. The instrument used was the Assessment of Stress Among Nursing Students (AEEE, Avaliação de Estresse em Estudantes de Enfermagem), prepared and validated in $2009 .{ }^{13}$

The AEEE is formed by 30 items and each item is assessed using a Likert scale with variable values from zero to three and positive values, i.e., the higher the score the greater the stress levels. The items are distributed into six domains: "Practical Activity Performance", "Professional Communication", "Time Management", "Environment”, "Professional Education" and "Theoretical Activity".

Students were instructed to score zero for "I do not experience this situation", number one for "I do not feel stress", number two for "I feel a little stressed with the situation" and number three for "I feel very stressed with the situation".

Score standardization was required because the total sum of the values attributed by the student for each domain was not directly compatible as the domains were formed by a different number of items. The values obtained for each one of the 30 items were added and the sum was divided by the number of items responded, excluding the number of items identified by zero to obtain the stress level per students. Items identified by zero were defined in the AEEE as "I do not experience this situation". The result minus 1 was multiplied by 50 . To verify the level of stress presented by each individual in each domain, the sum of the values given to the items was divided by the number of items in the domain, excluding the number of zeros. The result minus 1 was multiplied by 50 .

The stress level was classified using tertiles. After these measurements were calculated, the parameter for student classification was defined using the standardized score, ranging from 0 to $100 \%$, where the values from $0.00 \%$ to $33.33 \%$ represented a low stress level; $33.34 \%-66.67 \%$ represented a medium stress level and $66.68 \%-100 \%$ represented a high stress level.

A teacher investigator was responsible for applying the instruments in each institution. Data 
collection was from April 2011 to March 2012. Data were collected in the classrooms, at a time previously scheduled with the lecturers, from subjects who accepted to participate in the research and with the consent from the Nursing Course Coordination of each IES. The students were given the choice of completing the instruments at the scheduled time or to schedule another time to deliver them. Students who were not in the classroom at the time of collection were subsequently asked to participate in the Study.

The database was prepared using Excel for Windows (Office 2007) spreadsheets, using the Statistical Analysis System (SAS, version 9.01) and Statistica (version 7.1) programs. Pearson's chi-square test was used to verify the association between the sociodemographic characteristics and the stress level. Data were considered statistically significant when $p<0.05$, with a $95 \%$ confidence interval.

This study is part of a project entitled "Stress, coping, burnout, depressive symptoms and hardiness in nursing students and teachers," with interim collection and analysis in 2011 and 2012. This project was registered and approved by the Research Ethics Committee, with number 0380.0.243.000-10. An amendment to widen data collection to other institutions was subsequently requested and approved. In accordance with the Regulatory Guidelines and Standards for Research Involving Human Beings (Resolution N. 466/2012), the participants received an Informed Consent Form (ICF) which was signed after it had been read and the investigators had exposed and provided clarification on the nature of the study. ${ }^{14}$

\section{RESULTS}

There were 958 nursing students enrolled in the four courses under investigation. Admission criteria application excluded 161 nursing students, and 802 students were eligible to participate in the study. However, 52 students did not accept to participate and 45 did not return the study instruments. Thus, the study access population was formed by 705 students, which represents $87.90 \%$ of the study population. Of the total, $51.63 \%$ of the students were from private institutions and $48.37 \%$ were from public institutions, which showed equal subject distribution regarding type of institution.

The analysis of the internal consistency of the AEEE items yielded Cronbach's alpha, 0.889. The alpha values for the domains were the following: 0.757, for "Practical Activity Performance"; 0.757, for "Professional Communication"; 0.675, for "Time Management"; 0.732, for "Environment"; 0.769, for "Professional Education"; and 0.627, for "Theoretical Activities". These results were considered satisfactory since values over 0.6 show that the instrument's internal consistency is appropriate. ${ }^{15}$

Regarding sociodemographic characteristics, female students were the majority $(84.54 \%)$, in the $20-24$ year old range $(50 \%)$, single $(76.88 \%)$ and childless $(83.12 \%)$. Regarding residential status, $76.42 \%$ lived with relatives.

Regarding stress level, it was observed that $15.10 \%$ of the nursing students have high stress levels, $74.47 \%$ have medium stress levels and 9.93\% have low stress levels.

Table 1 shows the association between the sociodemographic variables and the students' stress levels.

Table 1 - Association between sex and age group, with nursing students' stress level, Santa Maria-RS, 2014. $(\mathrm{N}=705)$

\begin{tabular}{lccrrr}
\hline \multirow{2}{*}{ Variable } & \multirow{2}{*}{ Category } & \multicolumn{3}{c}{ Stress } & p \\
\cline { 2 - 4 } Sex & Female & $97(13.76)$ & $441(62.55)$ & $58(8.23)$ & 0.5003 \\
Age group & Male & $13(1.84)$ & $84(11.91)$ & $12(1.70)$ & \\
& $20 \_24$ & $\mathbf{7 0}(\mathbf{9 . 9 7 )}$ & $\mathbf{2 5 7 ( 3 6 . 6 1 )}$ & $24(3.42)$ & \multirow{2}{*}{$0.0003^{*}$} \\
& $25 \_29$ & $14(1.99)$ & $72(10.26)$ & $8(1.14)$ & \\
Institution & $>29$ & $17(2.42)$ & $93(13.25)$ & $13(1.85)$ & \\
& $<20$ & $9(1.28)$ & $100(14.25)$ & $\mathbf{2 5}(3.56)$ & \\
& Public & $\mathbf{7 8 ( 1 1 . 0 6 )}$ & $239(33.90)$ & $24(3.40)$ & $<0.00$ \\
\hline
\end{tabular}

* Statistically significant difference $(\mathrm{p}<0.05)$. 
Among the students, $75.64 \%$ did not practice sports, $60.53 \%$ practiced leisure activities and $74.25 \%$ of the students did not work. Regarding satisfaction with the course, $89.84 \%$ said they were satisfied and
$36.79 \%$ had already thought of dropping out.

Table 2 shows the association between the stress levels in the other sociodemographic variables for the nursing students.

Table 2 - Association between stress level of nursing students with the practice of sports, leisure activity, work activity, satisfaction and intention of dropping out of the course, Santa Maria-RS 2014. (N=705)

\begin{tabular}{|c|c|c|c|c|c|}
\hline \multirow{2}{*}{ Variable } & \multirow{2}{*}{ Category } & \multicolumn{3}{|c|}{ Stress } & \multirow{2}{*}{$\mathrm{p}$} \\
\hline & & High N (\%) & Medium N (\%) & Low N (\%) & \\
\hline \multirow[t]{2}{*}{ Sports } & Yes & $19(2.71)$ & $136(19.37)$ & $16(2.28)$ & 0.1425 \\
\hline & No & $91(12.96)$ & 386 (54.99) & $54(7.69)$ & \\
\hline \multirow[t]{2}{*}{ Leisure } & Yes & $63(9.21)$ & $314(45.91)$ & $37(5.41)$ & 0.5996 \\
\hline & No & $43(6.29)$ & $197(28.80)$ & $30(4.39)$ & \\
\hline Works & $\begin{array}{l}\text { Yes } \\
\text { No }\end{array}$ & $\begin{array}{r}17(2.42) \\
93(13.23)\end{array}$ & $\begin{array}{l}148(21.05) \\
375(53.34)\end{array}$ & $\begin{array}{l}16(2.28) \\
54(7.68)\end{array}$ & $0.0167^{*}$ \\
\hline \multirow[t]{2}{*}{ Satisfaction } & Yes & $90(12.88)$ & $471(67.38)$ & 67 (9.59) & $0.0024^{*}$ \\
\hline & No & $20(2.28)$ & 49 (7.01) & $2(0.29)$ & \\
\hline Drop out & $\begin{array}{l}\text { Yes } \\
\text { No }\end{array}$ & $\begin{array}{l}55(7.81) \\
55(7.81)\end{array}$ & $\begin{array}{l}192(27.27) \\
332(47.16)\end{array}$ & $\begin{array}{l}12(1.70) \\
58(8.24)\end{array}$ & $<.0001^{*}$ \\
\hline
\end{tabular}

* Statistically significant difference $(\mathrm{p}<0.05)$ *Yes and no represent whether the students practiced sports or not, practiced leisure activities are not, had work ties or not; was satisfied with the course or not and whether they had already thought of dropping out of the course or not.

It can be observed in table 2 that there was a statistically significant difference between stress and the following variables: work activity, satisfaction with the course and whether the student had already thought of dropping out of the course. Medium stress levels predominated among students who had not thought of dropping out of the course, who did not work and who were satisfied with the course.

\section{DISCUSSION}

Certain investigators highlight that some academic and sociodemographic characteristics of nursing students can influence their stress levels. ${ }^{13}$

However, in this study no statistically significant differences $(\mathrm{p}=0.5003)$ were found between sex and stress level. Although nursing is historically characterized as a profession with a predominance of females, in this study was not possible to state that women are more stressed than men. These data were different from the data in a study performed with 1617 university students in Turkey, in which the greatest stress scores were identified among female students. ${ }^{8}$ In other studies, it was observed that women can be more susceptible to stress than men, since they can be more spontaneous in ad- mitting stress or actually suffer more stress than men. ${ }^{8,16}$ The fact that female students have predominated in this study can have contributed for the non-appearance of the statistically significant difference between the sexes.

Regarding the age group associated to stress, there were significant differences $(p=0.0003)$, and there was a predominance of students aged 20-24 years, with medium stress levels (36.61\%), followed by high stress levels (9.97\%). A similar result was shown in the study developed with university students in Turkey, in which medium stress levels were observed in students aged 20-26 years. ${ }^{8}$ These data can be related to the possibility of students this age feeling insecure regarding the requirements of professional education and of the profession they have chosen. ${ }^{17-18}$ Furthermore, during the period of professional education, the student is faced with a new environment that is often quite different and distant from his contexts, where the need to adapt to new academic requirements and obligations can contribute to increase their stress levels. ${ }^{13}$

When stress is compared with the type of institution (public/private), a statistically significant difference was observed with the majority of private institution students having medium stress 
levels. These data can be related to the percentage of private institutions students who work (39.67\%), which is higher than the number of public institution students who work $(10.88 \%)$. Students can find it difficult to manage time and they assess this situation as a stressor, since conciliating studies with working activities includes the following: having little time to be with relatives, for leisure and to rest, lacking social interactions and spending time preparing to deliver the extracurricular requirements. ${ }^{7,13}$

No statistically significant differences were found in the comparison of the variables sports practice and leisure activities with stress, $\mathrm{p}=0.1425$ and $p=0.5996$ respectively. These data corroborated a study developed with workers from large companies that also verified there was no relationship between physical and leisure activity and stress. ${ }^{19}$ Nevertheless, these findings are different from other studies which have shown that people who practice physical activities have a greater tendency to show lower stress levels. ${ }^{20-21}$

A statistically significant difference was observed regarding work and stress level $(p=0.0167)$ and individuals who did not work presented medium stress levels (53.34\%). It should be emphasized that the students who dedicated themselves exclusively to the studies i.e. who did not work, were encouraged to participate in research groups, extension projects, monitoring, events and refresher courses. This may have influenced stress assessment by these students. ${ }^{7}$

There was also statistically significant difference between satisfaction with the course and stress level $(p=0.0024)$, and students who were satisfied presented medium stress levels $(67.38 \%)$. These data differed from other studies, which identified that students satisfied with their courses presented lower stress scores than those were not satisfied. ${ }^{8,22}$ These authors believe that stress resulting from dissatisfaction with the course can be a reason for the early interruption of academic education.

In this context, when the students were asked if they had already thought of dropping out of the course and this was associated to stress, a significant difference was observed $(p=<0001)$. Nevertheless, a medium stress level was predominant in the students who did not think of dropping out of the course $(47.16 \%)$.

Because of this, academic nursing education can be evaluated as stressful by the students. The need to help teachers and students to administer these stressful factors and start their professional career with less distress is important.

Understanding the stress level according to the various academic and sociodemographic variables of the nursing students can encourage proposals for changes aimed at reducing stress levels in nursing students and to permit a deeper knowledge of the students' characteristics and the main stressors.

\section{CONCLUSIONS}

The majority of nursing students presented medium stress levels, followed by high stress levels. This finding is similar to that of other studies and deserves attention from the parties involved in the teaching-learning process of nursing students since high levels of stress can interfere negatively in the process and in the students' health.

Regarding the associations, statistically significant differences between stress and the following variables were observed: age group, type of institution (public/private): work activity, satisfaction with the course and whether the student has already thought of dropping out of the course. Once the academic and sociodemographic characteristics of the nursing students and their stress levels are known, one can contribute to propose measures that minimize the effects of stress on these individuals. Moreover, once stress is minimized it is expected that students will have improved academic performance, less distress and more satisfaction by the time they enter the work market since the experiences the students had during their academic education are similar to those they face and professional life.

A limitation to this study is that few studies have been done on the theme, which made data comparison difficult. In addition, the results found cannot be generalized since the study was developed with four IES in two Brazilian regions. It is suggested that studies should be performed in different regions of the country in order to have a more ample data comparison.

Professional education is the time when students in general need to make important decisions that can be evaluated as a stressor. This study observed that academic education is evaluated as a stressor by students and that there is an association between the stress level and the academic and sociodemographic characteristic of nursing students. 


\section{REFERENCES}

1. Lazarus RS, Folkman S. Estresse, appraisal, and coping. New York (US): Springer; 1984.

2. Silva MCM, Gomes ARS. Stress ocupacional em profissionais de saúde: um estudo com médicos e enfermeiros portugueses. Estud Psicol [Internet]. 2009 [cited 2014 Jun 20]; 14(3):239-48. Available from: http://www.scielo.br/pdf/epsic/v14n3/a08v14n3. pdf

3. Santos AFO, Cardoso CL. Profissionais de saúde mental: manifestação de stress e burnout. Estud Psicol (Campinas) [Internet]. 2010 [cited 2014 Jun 20]; 27(1). Available from: http://www.scielo.br/pdf/estpsi/ v27n1/v27n1a08.pdf

4. Guido LA, Silva RM, Goulart CT, Kleinübing RE, Umann J. Stress and coping among surgical unit nurses of a teaching hospital. Rev Rene. 2012; 13(2):428-36.

5. Burnard P, Edwards D, Bennett K, Thaibah H, Tothova $\mathrm{V}$, Baldacchino D, et al. A comparative, longitudinal study of stress in student nurses in five countries: Albania, Brunei, the Czech Republic, Malta and Wales. Nurse Educ Hoje. 2008; 28(2):134-45.

6. Hsiao YC, Chien LY, Wu LY, Chiang CM, Huangs SY. Spiritual health, clinical practice stress, depressive tendency and health-promoting behaviours among nursing students. J Adv Nurs. 2010; 66(7):1612-22.

7. Bublitz S, Freitas EO, Kirchhof RS, Lopes LFD, Guido LA. Estressores entre acadêmicos de enfermagem de uma universidade pública. Rev Enferm UERJ [Internet]. 2012 [cited 2014 Jun 10]; 20(esp.2):73945. Available from: http://www.e-publicacoes. uerj.br/index.php/enfermagemuerj/article/ view/5992/4301

8. Bayram N, Bilgel N. The prevalence and sociodemographic correlations of depression, anxiety and stress among a group of university students. Soc Psychiatry Psychiatr Epidemiol. 2008; 43:667-72.

9. Moreira DP, Furegato ARF. Stress and depression among students of the last semester in two nursing courses. Rev Latino-Am Enfermagem [Internet]. 2013 [cited 2014 Jun 15]; 21(Spec):155-62. Available from: http://www.scielo.br/pdf/rlae/v21nspe/pt_20.pdf

10. Musso LB, Vargas BA, Torres MB, Canto MJC del, Meléndez CG, Balloqui MFK, et al. Fatores derivados dos laboratórios intra-hospitalares que provocam estresse nos estudantes de enfermagem. Rev LatinoAm Enfermagem [Internet]. 2008 [cited 2014 Jun 15]; 16. Available from: http:// www.scielo.br/pdf/rlae/ v16n5/pt_02.pdf

11. Amr A, El-Gilany AH, El-Moafee H, Salama L, Jimenez C. Stress among Mansoura (Egypt) baccalaureate nursing students. Pan African Medical J [Internet]. 2011 [cited 2014 Jun 20]; 8(26). Available from: http://www.panafrican-med-journal.com/content/ article/8/26/full/

12. Benavente SBT, Costa ALS. Respostas fisiológicas e emocionais ao estresse em estudantes de enfermagem: revisão integrativa da literatura científica. Acta Paul Enferm. 2011; 24(4): 571-6.

13. Costa ALS, Polak C. Construção e validação de instrumento para avaliação de estresse em estudantes de enfermagem (AEEE). Rev Esc Enferm USP. 2009; 4: 1017-26.

14. Ministério da Saúde (BR). Conselho Nacional de Saúde. Diretrizes e normas regulamentadoras de pesquisa em seres humanos. Resolução $\mathrm{N}^{\mathrm{o}} 466$, de 12 de dezembro de 2012. Brasília, 2012.

15. Malhotra NK. Pesquisa de marketing: uma orientação aplicada. $3^{\text {a }}$ ed. Porto Alegre (RS): Bookman; 2001.

16. Torquato JA, Goulart AG, Vicentin P, Correa U. Avaliação do estresse em estudantes universitários. Inter Science Place [Internet]. 2010 [cited 2014 May 28]; 14:140-54. Available from: http://www. interscienceplace.org/interscienceplace/article/ view/112/171

17. Freitas EO, Bublitz S, Neves ET, Guido LA. Sociodemographic and academic profile of nursing students of a public university. Rev Enferm UFPE on line [Internet]. 2012 [cited 2014 Mai 28]; 6(10):91523. Available from: http://www.revista.ufpe.br/ revistaenfermagem/index.php/revista/article/ view/3183/pdf_1537

18. Bublitz S, Guido LA, Kirchhof RS, Neves ET, Lopes LFD. Perfil sociodemográfico e acadêmico de discentes de enfermagem de quatro instituições brasileiras. Rev Gaúcha Enferm [Internet]. 2015 [cited 2015 Apr 20]; 36(1):77-83. Available from: http://www.seer. ufrgs.br/RevistaGauchadeEnfermagem/article/ viewFile/48836/33325

19. Farah BQ, Barros MVG, Júnior JCF, Ritti-Dias RM, Lima RA, Barbosa JPAS, et al. Percepção de estresse: associação com a prática de atividades físicas no lazer e comportamentos sedentários em trabalhadores da indústria. Rev Bras Educ Fís Esporte [Internet]. 2013 [cited 2014 May 20]; 27(2). Available from: http:// www.scielo.br/pdf/rbefe/v27n2/a07v27n2.pdf

20. Jonsdottir IH, Rodjer L, Hadzibajramovic E, Borjesson M, Ahlborg GJ. A prospective study of leisure-time physical activity and mental health in Swedish health care workers and social insurance officers. Prev Med. 2010; 51: 373-7.

21. He SB, Tang WG, Tang WJ, Kao XL, Zhang CG, Wong $X T$. Exercise intervention may prevent depression. Int J Sports Med. 2012; 3: 525-30. 
22. Faro A. Estresse e estressores na pós-graduação: estudo com mestrandos e doutorandos no Brasil. Psicol: Teor Pesq [Internet]. 2013 [cited 2014 May 28];
29(1):51-60. Available from: http://www.scielo.br/ pdf/ptp/v29n1/07.pdf 